\title{
Cigarette smoking induces small airway epithelial epigenetic changes with corresponding modulation of gene expression
}

\author{
Lauren J Buro-Auriemma ${ }^{1,2^{*}}$, Neil R Hackett ${ }^{1}$, Jacqueline Salit ${ }^{1}$, Matthew S Walters ${ }^{1}$, Yael Strulovici-Barel' \\ Michelle R Staudt ${ }^{1}$, Jennifer Fuller ${ }^{1}$, Melisa WY Ho${ }^{2}$, Ronald G Crystal ${ }^{1}$ \\ From Epigenetics and Chromatin: Interactions and processes \\ Boston, MA, USA. 11-13 March 2013
}

\section{Background}

The small airway epithelium (SAE), the first site of smoking-induced lung pathology, exhibits genome-wide changes in gene expression in response to cigarette smoking. Based on evidence that the epigenome can respond to external stimuli in a rapid manner, we assessed the SAE of smokers for genome-wide DNA methylation changes compared to nonsmokers, and whether these epigenetic changes were linked to the transcriptional program of these cells.

\section{Materials and methods}

SAE was recovered by fiberoptic bronchoscopy and brushing of healthy nonsmokers $(n=19)$ and healthy smokers $(n=20)$. SAE DNA was assessed for genome-wide methylation using the microarray-based high resolution Hpall tiny fragment enriched by ligation-mediated PCR (HELP) assay (Roche-NimbleGen). SAE transcriptome was assessed with Affymetirx HG-U133 Plus 2.0 arrays, with MAS5 and Ingenuity pathway analysis.

\section{Results}

Smoking caused methylation changes of $0.2 \%$ of genes distributed across the genome, with the majority characterized by hypomethylation and the minority by hypermethylation. Across the genome, 204 unique genes were differentially methylated in SAE DNA of smokers compared to nonsmokers, with $67 \%$ of the differential methylation within $2 \mathrm{~kb}$ of transcriptional start sites. For those genes affected, the methylation changes were limited to a focal region of the gene. Among the genes with differential methylation

${ }^{1}$ Department of Genetic Medicine, Weill Cornell Medical College, New York New York 10065 USA

Full list of author information is available at the end of the article were those related to metabolism, transcription, signal transduction and transport. Smoking induced hypomethylated genes were often related to xenobiotic processes and signal transduction, whereas smoking induced hypermethylated genes represented a wide variety of functions. Among the genes found to be differentially methylated by smoking were genes involved in SAE function of basal stem/ progenitor cells, cilia and secretory cells. Of the 204 differentially methylated genes, 34 (17\%) correlated with gene expression. Of these, $53 \%$ had hypermethylation linked to down-regulation and $47 \%$ hypomethylation linked to up-regulation. We also observed the opposite, with hypermethylation associated with up-regulation and hypomethylation linked to down-regulation.

\section{Conclusions}

The data demonstrates that the chronic stress to the lung by cigarette smoking is associated with significant changes in the DNA methylation status of the SAE, a cell population representing $<1 \%$ of the total lung parenchymal cell population, yet critical to normal lung function and defense. Many of these methylation changes are also linked to alterations of the SAE transcriptional program, indicating that epigenetic modifications likely play an important role in the pathogenesis of smoking-induced lung disease.

\section{Author details \\ ${ }^{1}$ Department of Genetic Medicine, Weill Cornell Medical College, New York, New York 10065 USA. ${ }^{2}$ Inflammation Discovery, Hoffman-La Roche, Nutley,} New Jersey 07110 USA.

Published: 18 March 2013 
doi:10.1186/1756-8935-6-S1-P10

Cite this article as: Buro-Auriemma et al:: Cigarette smoking induces small airway epithelial epigenetic changes with corresponding

modulation of gene expression. Epigenetics \& Chromatin 2013 6(Suppl 1): P10.

Submit your next manuscript to BioMed Central and take full advantage of:

- Convenient online submission

- Thorough peer review

- No space constraints or color figure charges

- Immediate publication on acceptance

- Inclusion in PubMed, CAS, Scopus and Google Scholar

- Research which is freely available for redistribution

Submit your manuscript at www.biomedcentral.com/submit 